\title{
Interpersonal Metadiscourse Markers in Turkish Election Rally Speeches Delivered by Pro-Turkish and Pro- Kurdish Leaders
}

\author{
By Elçin Esmer*
}

This study aims to analyze the use of interpersonal metadiscourse markers in Turkish election rally speeches delivered by two political leaders who pursued differently the ideology of nationalism and also the role of the metadiscourse markers in the reflection of the scope and nature of political parties' nationalist ideologies. In line with the aim of the study, the research has a descriptive survey design, using qualitative and quantitative approaches. The data for the study involves four election rally speeches: Two by Devlet Bahçeli and two by Selahattin Demirtaş in the span of the election year 2015. For the data analysis portion of the study, the finite verbs of the statements from the party leaders are abstracted and entered into the Nooj corpus processing system. Drawing on Dafouz's (2008) classification of interpersonal metadiscourse markers, a data analysis is done. Quantitative and qualitative methods are applied to identify the frequency of the metadiscourse markers used in the data. Moreover, the chi-square test is used to determine if there is meaningful difference between the two political leaders' usage of the metadiscourse markers. Results reveal that although both party leaders use similiar interpersonal metadiscourse markers in their election rally speeches, the metadiscourse markers have different functions due to their ideological viewpoints.

Keywords: Election rally speech, Interpersonal metadiscourse, Kurdish nationalism, Political speech, Turkish nationalism.

\section{Introduction}

Metadiscourse or reflexive discourse is broadly defined as the discourse about ongoing discourse (Adel 2006). Metadiscourse investigations have mostly focused on persuasive writings or speech produced in a number of different contexts such as textbooks (e.g. Crismore 1984, Hyland, 1999), academic research articles (e.g. Hyland 1999, Akbas 2012), post-graduate dissertation (e.g. Bunton 1999) and casual conversation (e.g.Schiffrin 1980). Neverthless, few studies (e.g. Ilie 2006, Ismail 2012) have investigated the function of metadiscourse markers in political speech which is one of the most important examples of persuasive speech genre. Political speech is used to convince voters and party supporters to take action as expected by political party leader or to change or weaken their current attitudes and beliefs (Van Dijk 1997, Kucukali 2014). Interpersonal metadiscourse is recognised as an important mean of facilitating communication between the text, producer and receiver. So it plays a vital role

\footnotetext{
* Assistant Professor, Mersin University, Turkey.
} 
for a political party/leader in interaction with his/her potential audience and persuading them.

This study is concentrated on the election rally speech that is a subgenre of political speech. It is delivered by party leaders focusing on positive self and negative other representation and in this genre there is a close interaction between party leader and audience (Kucukali 2014).

As said by Crismore and Abdollahzade (2010), countries outside Europe and the U.S. have paid little attention to metadiscourse analysis. During the literature survey, studies about such things were not found.

Nowadays the use of corpus linguistics (CL) methodology have become popular in critical discourse anlaysis (CDA) (Baker et al. 2008). Baker et al. (2008) stated that "CL examine frequencies, or, at least, provide strong indicators of the frequency, of specific phenomena recognized in CDA (e.g., topoi, topics, metaphors), by examining lexical patterns, and can add a quantitative dimension to CDA (p. 296)". During the literature survey, it was realized that the total number of both CL and CDA studies on metadiscourse is considerably limited in proportion to the number of corpus linguistics studies. So the study was framed in both CL and CDA perspectives.

The study aims to analyze the use of interpersonal metadiscourse markers in the Turkish election rally speeches delivered by two political leaders who pursued the ideology of nationalism in different dimensions: one is pro-Turkish and the other is pro-Kurdish. Also the study examines the interpersonal metadiscourse markers' role in the reflection of the scope and nature of political parties' nationalist ideologies.

\section{Literature Review}

The term "metadiscourse" coined by Zellig S. Harris (1959) has been investigated by a number of researchers (e.g. Adel 2006, Crismore 1984, Hyland 1998, 2004, 2005, Dafouz 2003, 2008). Many metadiscourse studies make use of Hallidayan distinction between the textual and interpersonal macrofunctions of language. According to these studies there are two levels of metadiscourse: the textual metadiscourse and interpersonal metadiscourse. Textual metadiscourse deals with the organization of discourse, i.e. how different pieces of information in a text are connected in a coherent way. As for interpersonal metadiscourse, it is recognised as an important means of facilitating communication between the text, producer and receiver. Interpersonal metadiscourse helps a text producer code his/her attitude towards both text content and text receiver (reader/audience) so it renders the text more reader/ audience friendly. In other words, text producer uses metadiscourse to express his/her professional personality and also guides or directs his/her readers through the text in order to persuade them.

Dafouz $(2003,2008)$ states although these levels fulfill similiar persuasive aims, their degree of persuasion is not the same. According to her, interpersonal metadiscourse holds a more persuasive function than the textual one. She 
developed a classification of interpersonal metadiscourse markers based on Crismore et al. (1993) categorization. The classification is presented in Table 1.

Table 1. Dafouz's (2008) Classification of Interpersonal Metadiscourse Markers

\begin{tabular}{|c|c|c|}
\hline Macro-category Hedges & Subcategory & Examples \\
\hline \multirow{3}{*}{$\begin{array}{l}\text { Express partial } \\
\text { commitment to the truth- } \\
\text { value of the text }\end{array}$} & Epistemic verbs & $\begin{array}{c}\text { May / might / it must be } 2 \\
\text { o'clock }\end{array}$ \\
\hline & Probability adverbs & Probably / perhaps / maybe \\
\hline & Epistemic expressions & It is likely \\
\hline \multicolumn{3}{|l|}{ Certainty markers } \\
\hline $\begin{array}{l}\text { Express total } \\
\text { commitment to the truth- } \\
\text { value of the text }\end{array}$ & & $\begin{array}{l}\text { Undoubtedly / clearly / } \\
\text { certainly }\end{array}$ \\
\hline \multicolumn{3}{|l|}{ Attributors } \\
\hline \multirow[b]{2}{*}{$\begin{array}{l}\text { Refer to the source of } \\
\text { information }\end{array}$} & & ' $\mathrm{x}$ ' claims that.../ \\
\hline & & $\begin{array}{c}\text { As the Prime Minister } \\
\text { remarked }\end{array}$ \\
\hline \multicolumn{3}{|l|}{ Attitude markers } \\
\hline \multirow{4}{*}{$\begin{array}{l}\text { Express writers' affective } \\
\text { values towards text and } \\
\text { readers }\end{array}$} & Deontic verbs & $\begin{array}{c}\text { Have to / we must } \\
\text { understand / needs to }\end{array}$ \\
\hline & Attitudinal adverbs & Unfortunately / remarkably \\
\hline & Attitudinal adjectives & It is absurd \\
\hline & Cognitive verbs & I feel / I think / I believe \\
\hline \multicolumn{3}{|l|}{ Commentaries } \\
\hline \multirow{6}{*}{$\begin{array}{l}\text { Help to establish reader- } \\
\text { writer rapport through the } \\
\text { text }\end{array}$} & Rhetorical questions & $\begin{array}{c}\text { What is the future of } \\
\text { Europe? }\end{array}$ \\
\hline & Direct address to reader & $\begin{array}{l}\text { You must understand, dear } \\
\text { reader }\end{array}$ \\
\hline & Inclusive expressions & $\begin{array}{l}\text { We all believe / let us } \\
\text { summarise }\end{array}$ \\
\hline & Personalizations & What the polls are telling me \\
\hline & & I do not want \\
\hline & Asides & $\begin{array}{c}\text { Diana (ironically for a } \\
\text { Spencer) was not of the } \\
\text { Establishment }\end{array}$ \\
\hline
\end{tabular}

As seen in the Table 1, Dafouz (2008) classification of interpersonal metadiscourse has five main categories that have particular functions: hedges, certainty markers, attributors, attitude markers and commentaries. Hedges and certainty markers act to strengthen or weaken the force of the text producer's statement. Hedges realized by epistemic verbs, probability adverbs and epistemic expressions weaken the strength of the text producer's statement while certainty markers expressed by adverbs of certainty strenghten the statement. As for attributors they are used by the text producer to support his/her statements. Attitude markers indicate the text producers affective values towards the receiver and the content of the text. These markers have four subcategory: deontic verbs, attitudinal adverbs, attitudinal adjectives, and cognitive verbs. The use of deontic verbs showing possibility and obligation positions the text 
producers as knowledgeable agents. Attitudinal adverbs and adjectives denote the producer's influence on the information. Cognitive verbs are used for the declaration of difference of opinion or criticism of another's ideas. Finally, commentaries realized by rhetorical questions, direct address to reader, inclusive expressions, personalizations and asides help build close relationship between the text producer and the receiver. According to Thompson (2001 cited in Dafouz 2008), "rhetorical questions" enable the text producer to encourage the receivers to accept his/her stance. As for the marker "direct adress to the reader", the text producer uses it to involve his/her receivers by relating the subject presented in the text to their lives. "Inclusive we" is used to shorten the distance between the producer and the receiver. In this way it shows solidarity with the receiver. "Personalization" refers to the explicit text producer's presence in the text. The use of the marker increases the producer's commitment to the statement and also the receiver (Mauranen 2002). Asides are generally presented in the brackets or parantheses in the written text. They are used by the text producers to insert his/her comments on the subject. Thus, they emphasize their point of views and shape their receiver's opinion (Temmerman 2013).

\section{Methodology}

\section{Research Design}

The study used the descriptive survey model that enables the researcher to identify the characteristics of the observed phenomenon as is (Baskarada 2014). Also in the study quantitative and qualitative methods were applied using the methodologies both CL and CDA. CDA provides the qualitative research tools, while corpus linguistics provides the quantitative research tools for the study of discourse.

\section{Data and Analysis}

The data for the study consists of four election rally speeches produced in the span of the election year 2015: Two by Devlet Bahçeli who is the leader of Nationalist Movement Party and two by Selahattin Demirtaş who is the leader of Peoples'Democratic Party.

The Nationalist Movement Party (Turkish: Milliyetci Hareket Partisi, MHP), is a Turkish far-right political party that adheres to Turkish nationalism and Euroscepticism. As to The Peoples' Democratic Party or Democratic Party of the Peoples (Turkish: Halkların Demokratik Partisi (HDP)), it is a proKurdish and pro-minority political party in Turkey.

Data Analysis was done based on Dafouz's (2008) classification of interpersonal metadiscourse markers that was explained above. Firstly in the study frequency analysis was conducted to identify the metadiscourse markers used in both sets of data. Then chi-square test was used to determine whether 
there was a significant difference between the two political leaders' usage of the metadiscourse markers.

The corpus was examined using the NooJ linguistic engine module, which allows NooJ users to sort the words and perform a morphological analysis on Turkish texts (Demirhan and Aksan 2011, Bisazzsa 2009).

\section{Findings and Discussion}

The quantitative analysis revealed that both party leaders employed the same metadiscourse markers and also their frequency order was quite similiar. As seen in Table 2, the results of the chi-square analysis showed that the value of observed chi-square was not significant $(\mathrm{p}=0.557<.05)$, indicating that there was not a significant difference between pro-Turkish and pro-Kurdish leaders in their use of total interactional metadiscourse markers.

Table 2. Results for Interpersonal Metadiscourse Categories and Subcategories

\begin{tabular}{|c|c|c|c|c|}
\hline \multirow{4}{*}{$\begin{array}{l}\text { Macro-category } \\
\text { Hedges }\end{array}$} & Subcategory & $\begin{array}{l}\text { Pro-Turkish } \\
\text { (f) }\end{array}$ & $\begin{array}{c}\text { Pro- } \\
\text { Kurdish(f) }\end{array}$ & Chi-Square \\
\hline & Epistemic verbs & & & \\
\hline & $\begin{array}{l}\text { Probability } \\
\text { adverbs }\end{array}$ & & & \\
\hline & $\begin{array}{l}\text { Epistemic } \\
\text { expressions }\end{array}$ & & & \\
\hline $\begin{array}{l}\text { Certainty } \\
\text { markers }\end{array}$ & & 72 & 68 & 0.0537 \\
\hline Attributors & & 11 & 9 & 0.0721 \\
\hline \multirow{4}{*}{$\begin{array}{l}\text { Attitude } \\
\text { markers }\end{array}$} & Deontic verbs & & & \\
\hline & $\begin{array}{l}\text { Attitudinal } \\
\text { adverbs }\end{array}$ & 0 & 2 & 0.0876 \\
\hline & $\begin{array}{l}\text { Attitudinal } \\
\text { adjectives }\end{array}$ & 3 & 3 & 0.0732 \\
\hline & Cognitive verbs & 1 & 0 & 0.0751 \\
\hline \multirow{5}{*}{ Commentaries } & $\begin{array}{l}\text { Rhetorical } \\
\text { questions }\end{array}$ & 32 & 27 & 0.0528 \\
\hline & $\begin{array}{l}\text { Direct address to } \\
\text { reader }\end{array}$ & 32 & 27 & 0.0528 \\
\hline & $\begin{array}{c}\text { Inclusive } \\
\text { expressions }\end{array}$ & 34 & 28 & 0.0644 \\
\hline & Personalizations & 11 & 8 & 0.0726 \\
\hline & Asides & & & \\
\hline $\begin{array}{l}\text { Total no. of } \\
\text { interpersonal } \\
\text { markers }\end{array}$ & & 172 & 191 & $0.0557 *$ \\
\hline
\end{tabular}

* The difference is significant at the 0.05 level $(\mathrm{p}<.05)$. 
The qualitative analysis of the corpus revealed that both leaders generally employed the same metadiscourse markers but the markers' functions were different throught the corpus.

Hedges are mitigating words or phrases such as sort of, probably. They are used to diminish the force of an utterance as well as save a speaker's face. According to Holtgraves and Lasky (1999) who studied on political speech, "A speaker who uses powerless language will be perceived as less assertive [or] competent... than a speaker who uses powerful language (p.196)". Paralel with this research, there is no hedge in the data. It can be explained by the fact that the party leaders concentrated predominantly on strengthening their position in front of their audience so they did not use hedges during their speech. The attributors were least frequently used in the both set of data (see Figure 1).

Figure 1. Frequency of Interpersonal Metadiscourse Markers

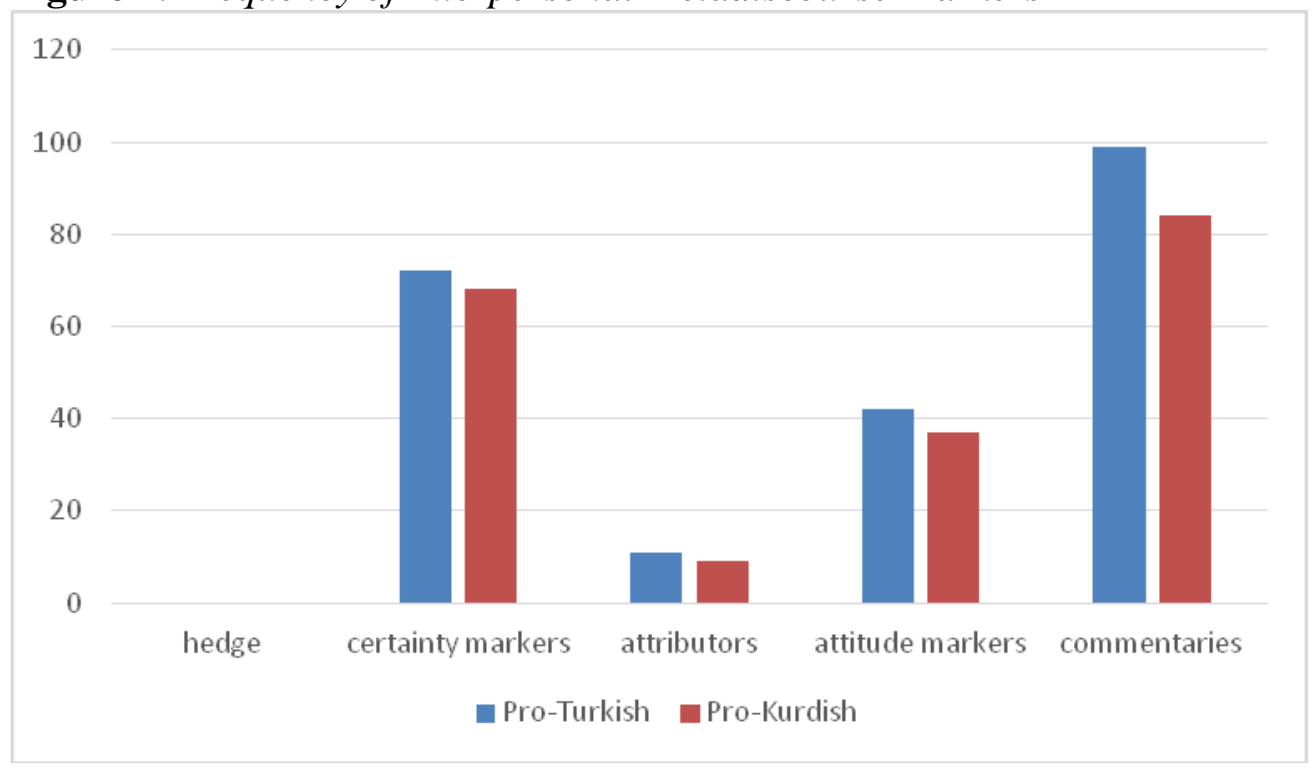

As seen in the following examples, both the leaders used attributors to criticize the opponents, especially the ruling party.

Pro-Turkish

Example 1

Erdoğan 4 yıl için milli uçağımız göklerde, Davutoğlu bugünlerde milli uçağımız yapılıyor dedi, ikisi birden yalan söylediler. [Erdoğan said that our çivil plane would be on the sky in the next four years, Davutoğlu said that our çivil plane was being built. Both of them told a lie].

\section{Pro-Kurdish}

Example 2

Cumhurbaşkanı başbakan olduğu dönemde "barajı biz koymadık ki biz kaldıralım" dedi. Ortada üst akıl falan yok. Hatırlarsan sen bize demiştim. "Baraj korkunuz yoksa parti olarak gir" demiştin, o aklı sen bize vermiştin. 
[when he was the prime minister the president said "We did not set the election threshold so we cannot remove it].

The certainty and attitude markers were used frequently in both election rally speeches and occupied a high position in the data (see Figure 1). The heavy use of these markers in the speeches indicated that the political leaders tend to more clearly express their personal feelings, concern and commitment in regard to the country's well being.

The most frequent certainty marker employed in the data was the modality suffix $-A c A k$ (will). The lexical certainty markers such as asla (never), kesinlikle (certainly), mutlaka (absolutely) occupied the second place in terms of frequency of occurence (see Figure 2).

Figure 2. Frequency of Certainty Markers

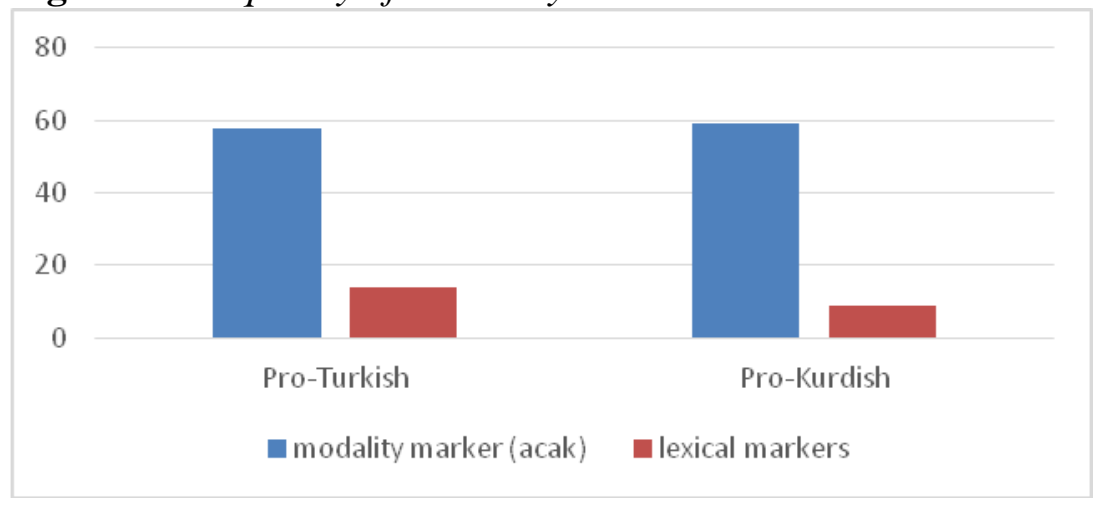

As seen in the following examples, the certainty markers were used to express certainty, strong intentions, determination and promise. This way the political leaders clearly expressed their parties' political targets and stance to win the elections.

\section{Pro-Turkish}

Example 3

Büyük Türk milletini şaha kaldıracağız ..bölücülüğün ve terörün kökünü kazıyacă̆ız... Mukaddesatımızı, tarihimizi, milli değerlerimizi maskaraya çeviren iç ve dış sürfelere asla firsat vermeyeceğiz. [We will rise the great Turkish nation up ... We will end the separatism and terror... We will never give an opportunity to the inner and foreign forces who ridicule our sacred values, our history, and our national values.]

\section{Pro-Kurdish}

\section{Example 4}

Yenikapıda bir araya gelen halk bizim düşmanımız değildir 8 haziranda da dostumuzdur kardeşimizdir beraber yaşayacă̆ız. Bunu unutmadan siyaset yapacağlz buna uygun bir yaşamı inşa edeceğiz ..Bu ülkede asla diktatörlüğe 
izin vermeyeceğiz. [People gathering in Yenikapı are not our enemies but our friends even on 8th of June, and we will live together. We will do politics without forgetting it, and we will build a life which is suitable for this. We will never allow dictatorship in this country].

In the example 3, Bahçeli promised with certainty that they would reproduce Turkish nationalism and destroy the illegal activities against Turkishness in accordance with his party's nationalist stance. Also he stated that they welcomed the other ethnic groups that are loyal to the Turkish state. However, in the example 4 , in accordance with his party's pluralist stance Demirtaş promised with certainty that they would live in peace with the other people, that is, Turkish people, and also they would create a decentralized pluralist, democratic administrative and political system based on the self-government of different groups and identities.

The attitude markers expressed the party leaders' affective values towards their audience and the content presented in the text. This way the party leaders tried to create solidarity between themselves and their audience. Attitudinal Adjectives were the most frequent resource in both groups. Attitudinal adverbs were the second most frequently used marker. Deontic and cognitive verbs occupied the lowest position in the data (see Figure 3).

Figure 3. Frequency of Attitude Markers

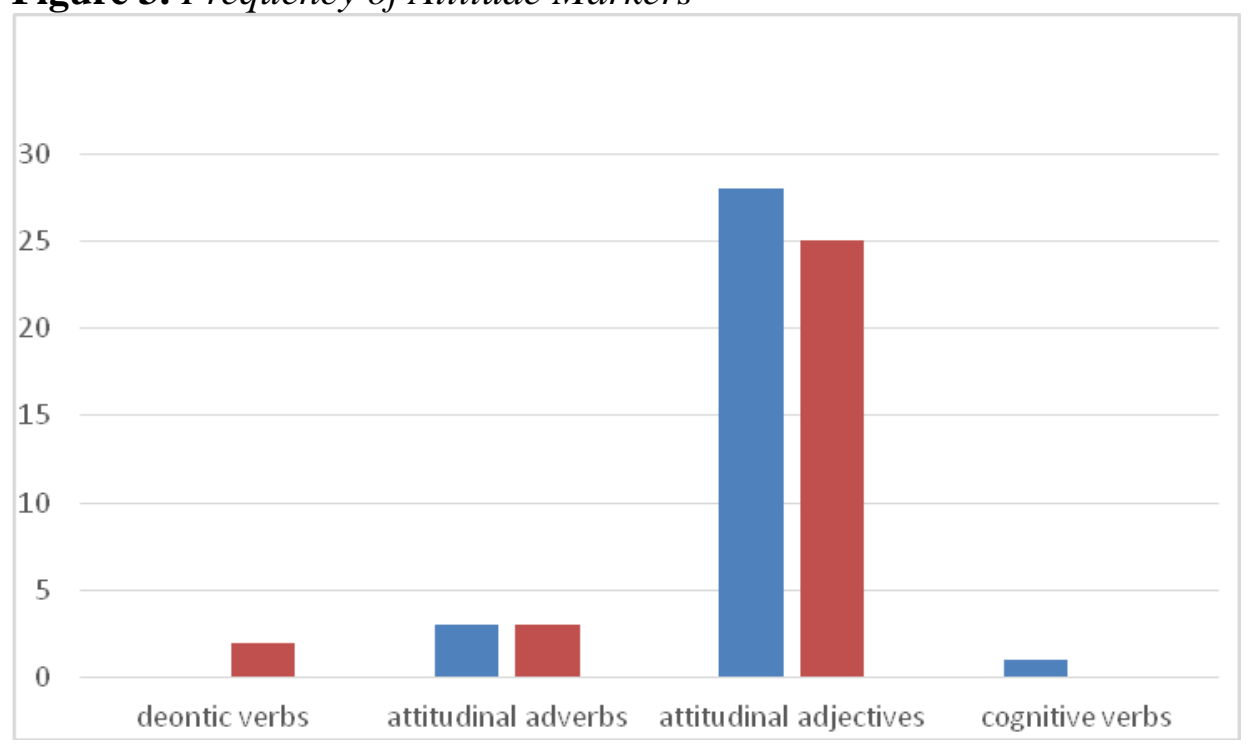

In the following example 5, the adjective büyük (great) and saygldeğer (respectful) were used to positively present what the Turkish have as inheritance. Through this statement Bahçeli created a lofty picture of the Turkish to show his positive feelings for his country and the other people who are not Turkish. This way, he tried to create a positive relationship with and enhance his acceptance by different people in the nation. As for the example 6, the positive adjective renkli (colorful) characterizes the pularist strategy and ideas of Demirtas and his party. With the use of this adjective, like Bahçeli, Demirtaş tried to create a positive relationship with, and enhance his acceptance by different people in 
Turkey. Also with the use of the deontic modal suffix "-mEli" (must/should) he criticized the inadequacies of the current Turkish parlementary system. He implied that the Turkish parlementary system does not consist of all ethnic groups, especially Kurdish people.

\section{Pro-Turkish}

\section{Example 5}

Biz her insanımızı büyük Türk milletinin saygıdeğer bir evladı olarak görüyoruz [We see all of our people as respectful children of the great Turkish nation]

\section{Pro-Kurdish}

Example 6

Parlamento renkli bir çiçek bahçesi olmalı. HDP'siz bir ülke, HDP'siz bir parlamento ancak tek renk kalır, gri olur gri, karamsar olur ama HDP'nin var olması demek parlamentoda güllerin açması demektir. [Parliament should be a colorful flower garden. A country without HDP, a parliament without HDP would be single-colored; it would be gray and gray is pessimism. The existence of HDP means roses are blossoming in the parliament.]

Through the statement in example 7, Bahçeli expressed his attitude to the AKP government policy. He used the negative adjectives (kötü (bad), Türk düşmanı (turcohope)) and the negative nouns (komplocular (plotter), Mehmetçik katilleri (robin killers)) to condemn the people or groups that are against the Turkish nation and support the illegal Kurdish movement. Also in the example 8 , Demirtaş used the negative adjectives çirkin (ugly), tekçil (monistic) to criticize and condemn the one nation- one flag ideology of the other parties. Through the statement "bizler bu oyuna, bu tuzağa düşmedik" (we did not fall into this game, this trap) he invited his audience to join his condemnation of the negative factors. Moreover, with this statement Demirtaş praised himself and his party indirectly while praising Turkish citizens and his supporters directly.

\section{Pro-Turkish}

\section{Example 7}

"Barzani, PKK, IŞID, HDP, Türk düşmanları, Mehmetçik katilleri, komplocular, çözümcüler, açılımcılar, kötü adamlar AKP'nin yanındadır." [Barzani, PKK, ISIS, HDP, enemies of Turks, murderers of Mehmetçik (robin killers-a special concept for soldiers), conspirators, resolutioners, initiative takers, bad guys are sided with AKP.] 


\section{Pro-Kurdish}

\section{Example 8}

Öylesine çirkin bir politikayla, tekçi politikalarla kutuplaştırdılar ki birbirimize selam veremeyecek hale gelelim istediler ama bizler bu oyuna, bu tuzağa düşmedik. [They have polarized us with such ugly policies, monistic politics that they wanted us to become people who cannot even greet each other; but we did not fall into this game, this trap.]

The commentaries were used most frequently in both sets of data and occupied the highest position in the data (see Figure 1). The significant use of commentaries disclosed that the leaders' strong commitment for establishing rapport with their audicences. As seen in the following figure, of the five various subtypes of commentaries, the rhetorical questions get the highest ranking, followed by inclusive expressions, direct addresses and personalizations. There is no aside in the data.

Figure 4. Frequency of the Commentaries' Subtypes in the Data

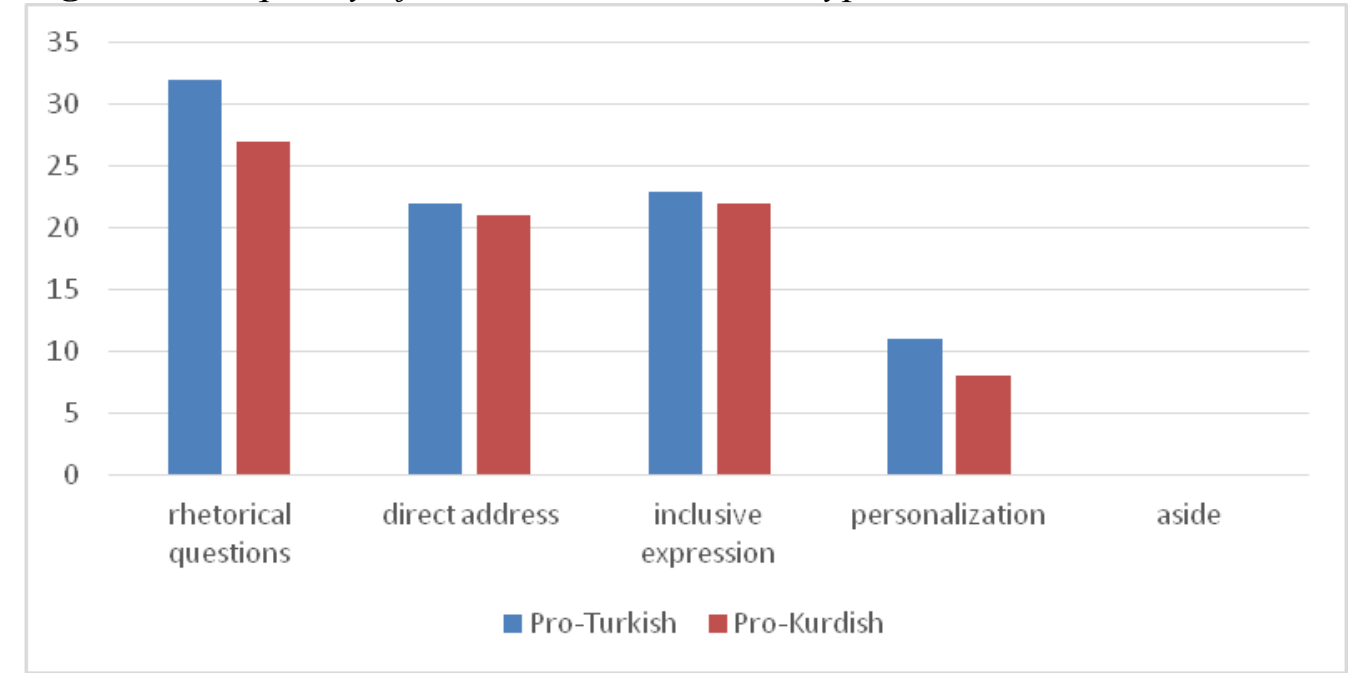

According to Wong and Ha YAP (2015), rhetorical questions are used by politicians to function as standpoints and as arguments and they often follow up their RQs with pre-determined elaborate answers. As seen in the following graphic, wh-questions were the most used resource in data. Because this type of question is more open ended and allow the leaders to avoid direct conflict with the supporters of other parties. The less use of yes-no questions and alternative types disclosed that party leaders are more mindful of diverse opinions. 
Figure 5. Frequency and Types of Rhetorical Questions

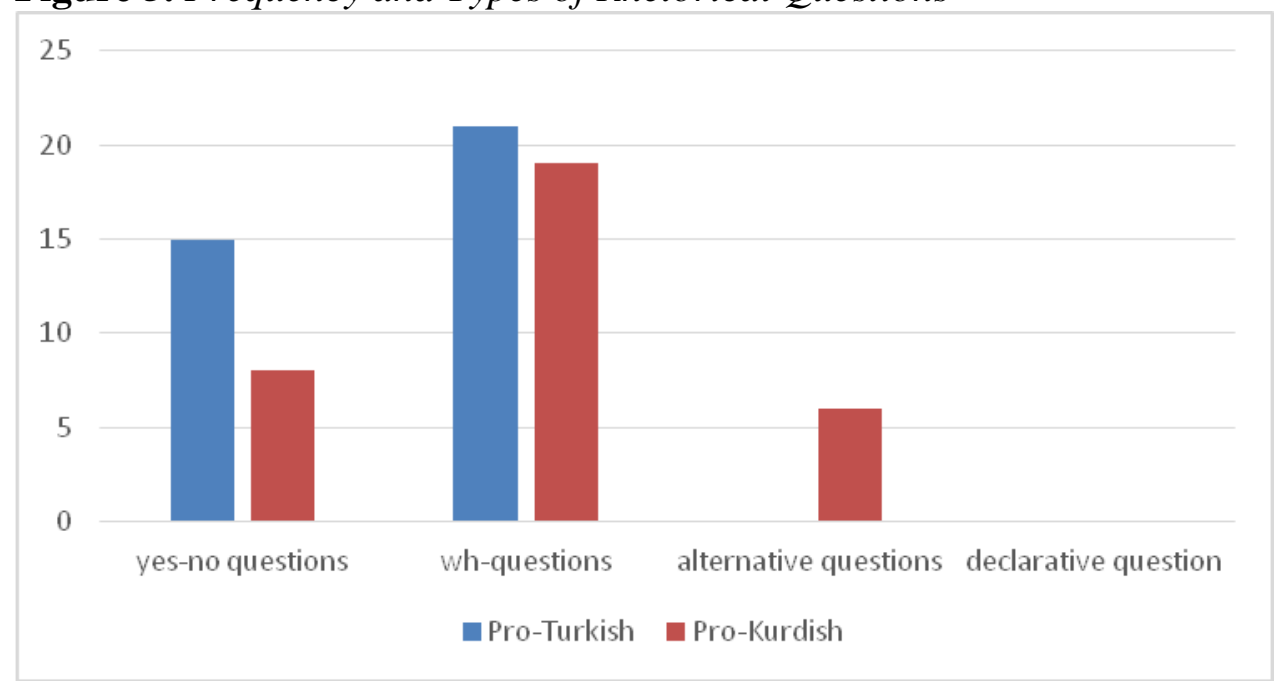

As seen in the following examples, both party leaders used wh-questions more frequently to critize Akp's Kurdish solution policy according to their nationalist ideologies.

\section{Pro-Turkish}

Example 9

Kerkük'te, Musul'da, Telafer'de, Tuzhurmatu'da Türkmenler katliama maruz kalırken nerelerdeydiniz? Türkmen kanı eline bulaşan Barzani'ye hangi maksatla silah gönderiyordunuz? [Where were you while Turkmens were being slaughtered in Kirkuk, Mosul, Tal Afar, Tuz Khormato? For what purpose were you providing weapons for Barzani who murdered Turkmens? ]

Pro-Kurdish

Example 10

Madem 76 milyonun Cumhurbaşkanıyım diyorsun da hangi yüzle bu 10 milyona ben sizin Cumhurbaşkanıyım diyeceksin? $\mathrm{Bu} 10$ milyon ne olacak? HDP süreci nerede engellemiş peki? [You say that "I am the President of the Republic of 76 millions", how will you say that "I am your President of the Republic" to those 10 millions? What is going to happen to those 10 millions? How did HDP prevent the process?]

In the example 9, Bahçeli accused of the government not helping Turkmen who live in the border of Syrian and support the illegal actions of Barzani and PKK. On the other hand, in the example 10, Demirtaş accused of the government breaking the Kurdish solution process and preventing HDP's accession to the parliament. As seen in the following examples, both party leaders used yes-no questions to unfold their vision and criticize their opponents. 


\section{Pro-Turkish}

\section{Example 11}

Bayrağımıza sahip çıkacak mısınız? (Evet)Vatanımıza sahip çıkacak mısınız? (Evet)Türkiye'mize sahip çıkacak mısınız? (Evet) (Will you protect our flag? [Yes)Will you protect our country? (Yes) Will you protect our Turkey? (Yes)]

\section{Pro-Kurdish}

\section{Example 12}

Yenikapı'da bir araya gelen halk bizim düşmanımız değil. 8 Haziran'da da dostumuzdur, kardeşimizdir, beraber yaşayacağız. Bunu unutmadan siyaset yapacağız ve buna layık bir yaşamı inşa edeceğiz. Bunu söyleyen parti var mı? Yok maalesef. [The people gathering in Yenikap1 are not enemies of us. They are our friends, brothers and sisters on the 8th of June too, we will live together. We will do politics without forgetting this and we will build a life suitable for this. Are there any parties stating that? Unfortunately, not.]

In example 11, Bahçeli self-promoted himself and he tried to gain the support or aggrement from the audience by embedding an implicit message that MHP is the only party which defends and protects Turkishness. By contrast, in the example 12 Demirtaş self-promoted himself and he tried to gain the support or aggrement from the audience by embedding an explicit message that HDP is the only party which hugs all people from different ethnic groups in Turkey and brings internal peace. This way Demirtaş and Bahçeli stimulated their supporters and swing voters to look into what they can do in comparison to their opponents and also expressed their determination to make the changes to the country.

In the data, alternative type of question was seen only in the speech of Demirtaş. He used the alternative questions to induce doubt inside the mind of audience and this way he gives the audience more freedom to get the implied message. However, the alternative question is "not always neutral" with respect to the speaker's desire (Van Rooy and Safarova 2003: 304). As seen in the following example, Demirtas wanted the audience to select the second option, which is consistent with his ideology.

\section{Example 13}

"Bundan sonra görüşme olmayacak, kimse İmralı adasına gitmeyecek" diyen ben miyim Cumhurbaşkanı mı? [Is the one saying "There will be no more meetings, nobody will go to İmralı island" me or the President of the Republic?]

Also, the subtypes of commentaries "direct address to the reader", "the inclusive expression" and "personalisation categories" used by the two leaders have a similar frequency (see Figure 4). 
As seen in the following example 14, in accordance with his nationalist ideology, Bahçeli started his speech with the term "Büyük Türk milleti (Grate Turkish Nation)" to show his positive feelings to the Turks. With this term he more or less implicitly reminded that the Turks have a big history and this way he tried to stir the nationalist feelings of the Turks. Also he used the terms "degerli vatandaşlarım (my dear fellow citizens), kardeşlerim ( my brothers)" to show that he acknowledged all nationalities and ethnicities being loyal to the Turkish state. On the other hand, in the example 15, Demirtaş began his address by calling the people "değerli kardeşlerim, arkadaşlarım (dear brothers and friends)" in accordance with his pularist ideology. During his speech, beside the terms he addresed the people "Barışa hasret tüm halklar (all people who long for peace)". It can be said that Demirtaş's form of address is more inclusive than Bahçeli.

\section{Pro-Turkish}

\section{Example 14}

Büyük Türk Milleti, Değerli Vatandaşlarım,Yokluk ve yoksulluktan daralan kardeşlerim, Evladının kaygısını duyan, vatan için yüreği çarpan, Barışmak, kucaklaşmak için firsat arayan aziz vatandaşlarım. [Great Turkish Nation, my Valuable Citizens, my brothers and sisters who were suffocated by poverty, My dear citizens who worry about their children, whose hearts are beating for the country, who seek for an opportunity to make peace and embrace].

\section{Pro-Kurdish}

\section{Example 15}

Değerli kardeşlerim arkadaşlarım bütün kardeşlerim.Barışa hasret tüm halklara sesleniyorum. [Dear brothers and sisters, and friends. I speak to all people who long for peace].

The use of the "inclusive we" including both politician and audience creates politician-audience solidarity. As seen in the following examples, with the use of the "inclusive we", both party leaders tried to give collective identity to the audience and himself. By doing so, they tried to remind the people that he belongs to them and he is one of them.

Bahçeli used "biz (we)" twenty times, "bizim (our) fifteen times" and "bize (us)" seven times. As seen in the following example 16, he used the pronouns "biz" and "bize" inclusively to include all people in Turkey. Also, Demirtaş used "biz" sixteen times, "bizim" seven times and "bize" 5 times. However, he used only the pronoun "biz" inclusively to address all nationalities and ethnicities in Turkey (see example 17). 


\section{Pro-Turkish}

Example 16

Üçüncüsü bu silahları eline geçirenler veya gasp edenler yarın hasım hale gelirlerse bize yöneltmeyeceklerinin garantisi var mıdır? Biz yürürsek karşımıza kimseler çıkamayacaktır. [As the third, is there any guarantee that those weapons will not be turned against us if those people who seized or hijacked those weapons become enemies of us? If we move, nobody could stand in front of us.]

\section{Pro-Kurdish}

\section{Example 17}

Bizler farklı farklı kimliklere sahibiz. Biz bunu değiştiremeyiz. İnançlarımız var, mezheplerimiz var. [We have various identities. We cannot change that. We have beliefs, religious fractions.]

Moreover, in some instances, the party leaders used "biz, bizim, bize" exclusively to emphasize their leadership role.

\section{Pro-Turkish}

\section{Example 18}

Laik olanını, dindarını, Alevisini Sünnisini, doğulusunu batılısını, güneylisini kuzeylisini herkesi kucaklamaya hazırız. Biz gönülleri, vicdanları, umutları üç hilalde birleştirdik“Bize sökmez, bize fark etmez. Milliyetçi Hareket'e diş geçmez, önüne geçilemez, hiçbir tehlike de bize hüküm süremez. Ne var ki hala bizimle uğraşıyorlar. [We are ready to embrace laic people, religious people, Alevites, Sunnites, Easterners and Westerners, Southerners and Northerners. We have united in our hearts, consciences, and hopes with three crescents; it does not matter to us. Milliyetçi Hareket (Nationalist Movement) cannot be ordered, prevented, and no dangers can rule over us. Yet they are still messing with us.]

\section{Pro-Kurdish}

Example 19

Cumhurbaşkanlığının imkanlarıyla bize karşı bir kampanya yürüttüler. Partimizi itibarsızlaştırmaya çalıştılar. Biz bütün bunlara karşı ne yaptık peki? $\mathrm{Bu}$ provokasyona gelmeyeceğiz, savaşa izin vermeyeceğiz dedik ve çıkıp kardeşlik mesajları verdik. Bugüne kadar barajı aşamadık. Tamamı bizim eksikliğimizdi. Kendimizi anlatamadık. Bu suç bu hata bizimdi. Ama şimdi 81 ülkede herkese gönlümüzü açtık. [They have run a campaign against us by the resources of the Presidency of the Republic. They have tried to discredit our party. What have we done in return to this? We said that would not fall into this provocation; we would not allow the war, and we have given 
brotherhood/sisterhood messages. We were not able to pass the election threshold so far. It was all our deficiency. We could not express ourselves. This blame, this mistake was ours. But now, we have opened our hearts to everyone in 81 cities.]

In the example 18, Bahçeli used the pronouns "biz" and "bizim" exclusively to refer MHP. Also in the example 19, Demirtaş used the pronouns "biz", "bizim" "bize" exclusively to refer his party (HDP).

As seen in the following examples, the party leaders used the pronoun Ben (I) to present themselves as individuals, speak from their own perspective and also highlight their good qualities and accomplishments. This finding is consistent with Bramley (2001).

Bahçeli used the pronoun "Ben" (11 times) to distinguish himself from the government and puts himself in a mostly positive light. This way, he critizes the ruling party's policies. In the example 20 , he implied that the ruling party is a liar, trickster but his party is trustworthy and it does not tolerate unfairness. As for Demirtaş, he used the pronoun "Ben" ( 8 times) to give information about his personal life. By doing so, he let people know him as a person not only as a politician. In the example 21 , he implied that he shared the same pain with the audience. Also with the use of Ben in the statement "yine barlş dedim" he distinquished himself from other politicians and puts himself in a mostly positive light. He implied that he is the only leader insisting on the peace.

\section{Pro-Turkish}

Example 20

Şimdi ben unuttuklarını hatırlatayım:Milliyetçi Hareket Partisi haklı olduğu bir konuda, engel tanımaz, haksızlığa boyun eğmez, yapay bariyerleri yıkar geçer. Ben bunlara boşuna yalanc1, boş yere riyakar demiyorum. [Now, let me remind what they have forgotten: Milliyetçi Hareket Partisi (National Movement Party) never stops at and never submits to anything that it is right about. It is not for nothing for me to call those people liars and hypocrites.]

\section{Pro-Kurdish}

Example 21

Diyarbakır mitinginde benim kardeşlerimin, yoldaşlarımın yanmış cenazeleri benim önümden götürüldü, ben onların acısını yüreğime gömdüm, çıkıp yine barış dedim. [At the Diyarbakır meeting, burned bodies of my brothers/ sisters and my fellows have been carried in front of me. I have buried their pains in my heart and said "peace" again.] 


\section{Conclusion}

The analysis of the corpus revealed that although both the leaders employed the same metadiscourse markers, the markers appeared to function differently throught the corpus due to the leaders' ideological viewpoints. This finding supports Oktar's (2001) view "ideology is an important "determining factor in the organization of discourse in terms of social representation of us versus them (p.344) ".

Nationalism is the political and public expression of national identity (Huysseune 2002). National identity is one's identity or sense of belonging to one state or to one nation. It is psychologically seen as "an awareness of difference", a "feeling and recognition of 'we' and 'they'" (Lee, 2012). All elements and values in culture such as language, religion, flag, history, homeland, government, lifestyle determine one's national identity (Eker 2009 cited in Gelisli 2014). Therefore, national identities are subject to constant change. According to De Cillia et al. (1999), "national identities - conceived as specific forms of social identities - are discursively, by means of language and other semiotic systems, produced, reproduced, transformed and destructed (p. 153)". The findings obtained in the study disclosed that with the help of the interpersonal metadiscourse markers, Bahçeli tried to reproduce their audiences' national identities while Demirtaş tried to transform them. In other words, Bahçeli used the metadiscourse markers to show his party's less-interested in ethnicity and emphasize Turkishness more broadly and inclusively based on his party's nationalist ideology that centres on belief in the prestige of the Turkish state. This way he tried to evoke a sense of patriotism and restore the national values. As for Demirtaş, he used these markers to show his party's less interested in nationalism and emphasize the party's pluralist political system that unify and represent all groups, especially the Kurdish one, in terms of ethnicity and nation. This way he tried to unite and reconstitute the nation on the behalf of the Kurdish people.

\section{References}

Adel A (2006) Metadiscourse in L1 and L2 English: Annelie Adel, vol. 24. John Benjamins Publishing Co.

Akbas E (2012) Interactional metadiscourse in Turkish postgraduates' academic texts: A comparative study of how they introduce and conclude. Journal on English Language Teaching 2(3): 35-45.

Baker P, Costas G, Majid K, Michal K,. Tony M, Wodak R (2008) A useful methodological synergy? Combining critical discourse analysis and corpus linguistics to examine discourses of refugees and asylum seekers in the UK press. Discourse \& Society 19(3): 273-306.

Baskarada S (2014) Qualitative case study guidelines. The Qualitative Report 19(40): $1-18$.

Bisazza A (2009) Designing a NooJ module for Turkish. Proceedings of NooJ Conference 2009. 
Bramley NR (2001) Pronoun of Politics: the use of pronouns in the construction of "self" and "othe" in political interview. Ph.D Diss., The Australian National University.

Bunton D (1999) The use of higher level metatext in $\mathrm{PhD}$ theses. English for Specific Purposes 18 (Suppl. 1): S41-S56.

Crismore A (1984) The rhetoric of textbooks: metadiscourse. Journal of Curriculum Studies 16(3): 279-296.

Crismore A, Abdollahzadeh E (2010) A review of recent metadiscourse studies: the Iranian context. NJES 9(2): 195-219.

Crismore A, Markkanen R, Steffensen MS (1993) Metadiscourse in persuasive writing: A study of texts written by American and Finish university students. Written Communication, 10(1): 39-71.

Dafouz E (2003) Metadiscourse revisited: A contrastive study of persuasive writing in Professional discourse. Estudios Ingleses de la Universidad Complutense 11: 29-52.

Dafouz E (2008) The pragmatic role of textual and interpersonal metadiscourse markers in the construction and attainment of persuasion: A cross-linguistic study of newspaper discourse. Journal of Pragmatics 40: 95-113.

De Cillia R, Reisigl M, Wodak R (1999) The discursive construction of national identity. Discourse and Society 10(2): 149-173.

Demirhan UU, Aksan M (2011) Tagset for NooJ Turkish module. NooJ Conference 2011: 13-15. June 2011, Dubrovnik, Croatia.

Gelisli Y (2014) The development study of national identity perception scale. International Journal on New Trends in Education and Their Implications 5(4): 1-11.

Harris ZS (1959) The transformational model of language structure. Anthropological Linguistics 1(1): 27-29.

Holtgraves TM, Lasky B (1999) Linguistic power and persuasion. Journal of Language and Social Psychology 18: 196-205.

Huysseune M (2002) Nationalism and identity politics in international relations. In International Relations, Encyclopedia of Institutional and Infrastructural Resources, Unesco Encyclopedia Of Life Support Systems (EOLSS), J Wiener (Ed), 32-57.

Hyland K (1998) Persuasion and context: The pragmatics of academic discourse. Journal of Pragmatics 30: 437-455.

Hyland K (1999) Talking to students: Metadiscourse in introductory coursebooks. English for Specific Purposes 18(1): 3-26.

Hyland K (2004) Disciplinary interactions: Metadiscourse in L2 postgraduate writing. Journal of Second Language Writing 13: 133-151.

Hyland K (2005) Metadiscourse: Exploring interaction in writing. Oxford: Continuum.

Ilie C (2006) Parliamentary Discourses. In Encyclopedia of Language and Linguistics 2nd Edition, Vol. 9, K Brown (Ed), 188-197. Oxford: Elsevier.

Ismail MH (2012) Discourse markers in political speeches: Form and functions. Journal of College of Education for Women 23(4): 1260-1278.

Kucukali C (2014) The perceptions, attitudes and political strategies of "Die Linke": apolitical discourse analy-sis. GeT MA Working Paper No. 2. Department of Social Sciences, Humboldt-Universität zu Berlin. [online] Homepage: Edoc Server Humboldt-Universität zu Berlin.

Lee Y (2012) Modern education, textbooks, and the image of a nation. London: Routledge.

Mauranen A (2002) "One Thing I'd Like to Clarify...". Observations of Academic Speaking. Helsinki English Studies 2: 1-10. Retrieved from http://bit.ly/2jKWbRv. 
Oktar L (2001) The ideological organization of representational processes in the presentation of US and THEM. Discourse \& Society 12(3): 313 - 346. Sage Publications.

Schiffrin D (1980) Metatalk: Organizational and evaluative brackets in discourse. Sociological Inquiry 50: 199-236.

Temmerman M (2013) Forms and functions of asides in print media interviews. SLE 2013. University of Split. Book of abstracts.

Thompson $\mathrm{G}$ (2001) Interaction in academic writing: Learning to argue with the reader. Applied Linguistics 22(1): 58-78.

Van Dijk T (1997) What is the political discourse?. Belgian Journal of Linguistics: Political Linguistics, J Blommaert, Ch Bulcaen (Eds.). Amsterdam: John Benjamins Company.

Van Rooy R, Safarova M (2003) On polar questions. In Proceedings of SALT 13: 292309.

Wong S, Ha Yap F (2015) Did Obama care create new jobs?An analysis of Mitt Romney's use of rhetorical questions in the 2012 US presidential election campaign. Text \& Talk 35(5): 643-668. 